\title{
Connection Temperatures during the Mokrsko Fire Test
}

\author{
J. Chlouba, F. Wald
}

The Mokrsko fire test focused on the overall behaviour of the structure, which cannot be observed on the separate elements, and also on the temperature of connections with improved fire resistance. During the test, measurements were made of the temperature of the gas and of the elements, the overall and relative deformations, gas pressure, humidity, the radiation of the compartment to structural element and the external steel column, transport of the moisture through the walls, and also the climatic conditions. The results of the test show the differences between the behaviour of the element and the behaviour of the structure exposed to high temperatures during a fire. The collapse of the composite slab was reached. The results of the numerical simulations using the SAFIR program compared well with the measured temperature values in the structure and also in the connections.

Keywords: Fire test, FE simulation, fire safe connection, temperature prediction, Angelina beam, compartment fire.

\section{Introduction}

The Mokrsko fire test focused on the overall behaviour of the structure, and on the connection temperatures, neither of which can be observed on the separate elements. In addition to three types of flooring systems, six wall structures with mineral wool were tested.

The fire experiment was conducted in Mokrsko, Central Bohemia, Czech Republic, $50 \mathrm{~km}$ south from Prague, on 18 September 2008, see [1]. The new building was set up at the Joseph Underground Educational Facility of the Czech Technical University in Prague, see www.uef-josef.eu. The experiment follows on from the seven large-scale fire tests at the Cardington laboratory on steel frames from 1998-2003, see [2]. Knowledge acquired during the Ostrava fire test was also used during the experiment, see [3] and [4]. The structure was designed by the EXCON a.s. Prague design office, in cooperation with all parties involved in delivery of the structural parts. The fire design of the structure was prepared at the Czech Technical University in Prague, the University of Sheffield and the Slovak Technical University in Bratislava. The behaviour of slender castellated beams and beams with a corrugated web, including the concrete slab and the connection behaviour at elevated temperatures, were simulated using the VULCAN programme.

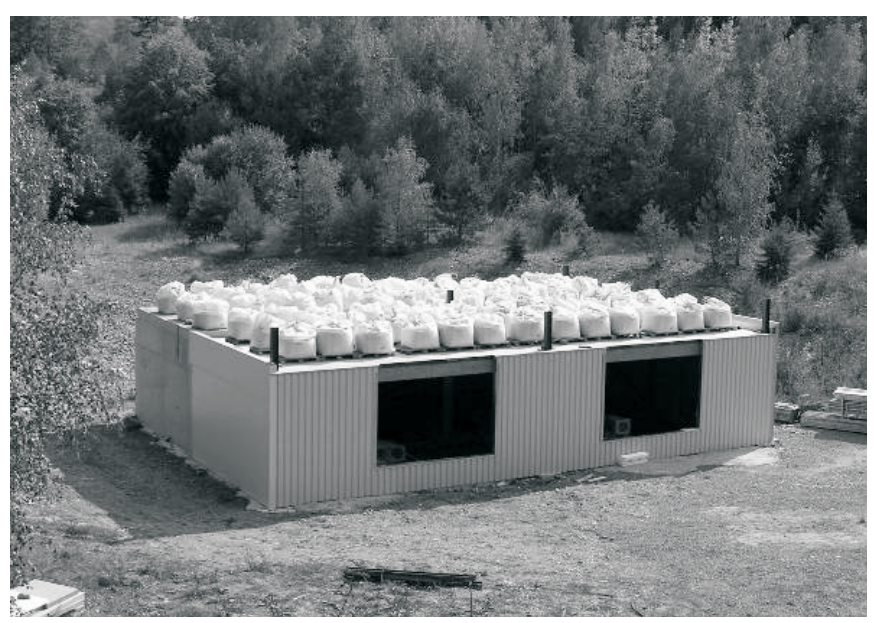

Fig. 1: Experimental building

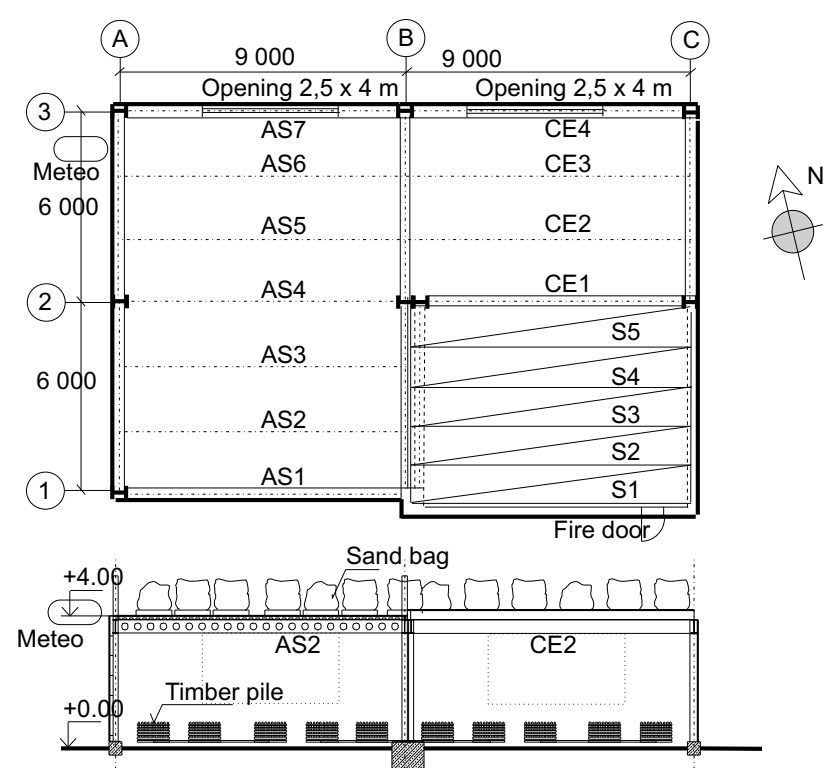

Fig. 2: Plan view of the structure

\section{Experimental structure}

The structure represents one floor of an administrative building $18 \times 12 \mathrm{~m}$ in size, see Fig. 1 and Fig. 2. The composite slab on the castellated beams was designed with a span 9 to $12 \mathrm{~m}$ and on beams with corrugated webs with a span 9 to $6 \mathrm{~m}$. The deck was a simple trapezoidal composite slab $60 \mathrm{~mm}$ in thickness, $120 \mathrm{~mm}$ in height over the rib with CF46 sheeting (Cofraplus $0.75 \mathrm{~mm}$ ) and concrete of measured cubic strength $34 \mathrm{~N} / \mathrm{mm}^{3}$ in 28 days reinforced by a smooth

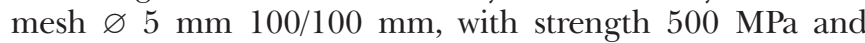
coverage $20 \mathrm{~mm}$. The Spiroll prefabricated panels $320 \mathrm{~mm}$ in height with hollow core openings formed a $9 \mathrm{~m}$ span. The panels were supported by a concrete wall and a primary hollow beam from welded double IPE 400 section. The castellated beams with sinusoid Angelina openings, designed by ArcelorMittal, made of an IPE 270 section from steel S235 were $395 \mathrm{~mm}$ in height. The beams with corrugated webs, designed by Kovové profily s.r.o., had flanges $220 \times 15 \mathrm{~mm}$ and a web $2.5 \mathrm{~mm}$ in thickness and $500 \mathrm{~mm}$ in height, using 
steel S320. The edge beams were from IPE 400 steel S235 sections. The fire protected columns were prepared from HEB 180 sections. The horizontal stiffness of the frame was achieved with concrete walls $250 \mathrm{~mm}$ in thickness, made of C30/37 concrete, and two cross braces of L $80 \times 80 \times 8$. The beam-to-beam and beam-to-column connections were designed as a header plate, plate $10 \mathrm{~mm}$ with four M16 bolts class 8.8. Improved fire resistance was achieved by encasing two bolts in the concrete of the slab.

Two walls were composed from cladding, linear trays, mineral wool and external corrugated sheets. In two $6 \mathrm{~m}$ spans, a comparison was made of the system with the internal grid and horizontal sheeting and with vertical sheeting without the internal grid. Two other walls were made of sandwich panels $150 \mathrm{~mm}$ in thickness, filled with mineral wool. In front of the concrete wall there was a brick wall made of plaster blocks. The fire protection of the columns, primary and edge beams, and also the bracings, was designed for R60 by Promatect H $2 \times 15 \mathrm{~mm}$ board protection.

\section{Mechanical and fire load}

The mechanical load was designed to comply with the load for a regular administrative building. The dead load of the tested structure was $2.6 \mathrm{kN} / \mathrm{m}^{2}$. The variable load $3.0 \mathrm{kN} / \mathrm{m}^{2}$ was simulated by 78 sand bags with road metal. The weight of the bags varied from $793 \mathrm{~kg}$ to $1087 \mathrm{~kg}$. They were coupled on pallets in threes to achieve an average weight $900 \mathrm{~kg}$, see Fig. 3. The applied load represented the characteristic value of the variable action at elevated temperature $3.0 \mathrm{kN} / \mathrm{m}^{2}$ and characteristic value of flooring and partitions $1.0 \mathrm{kN} / \mathrm{m}^{2}$.

The $15 \mathrm{~m}^{3} 50 \times 50 \mathrm{~mm}$ unwrought wooden cribs $1 \mathrm{~m}$ in length of softwood dried to moisture till $12 \%$ formed the fire load. The cribs were placed into 50 piles, see Fig. 4 . Each pile consisted of 12 rows with 10 cribs, i.e., $35.5 \mathrm{~kg} / \mathrm{m}^{2}$ of timber, and simulated a fire load of $620 \mathrm{MJ} / \mathrm{m}^{2}$. The design characteristic fire load of an administrative building is calculated as $420 \mathrm{MJ} / \mathrm{m}^{2}$. Simultaneous ignition of the piles was achieved by connecting them using steel thin-walled channels filled with mineral wool and penetrated by paraffin. The channels were located on the second layer of cribs, and connected

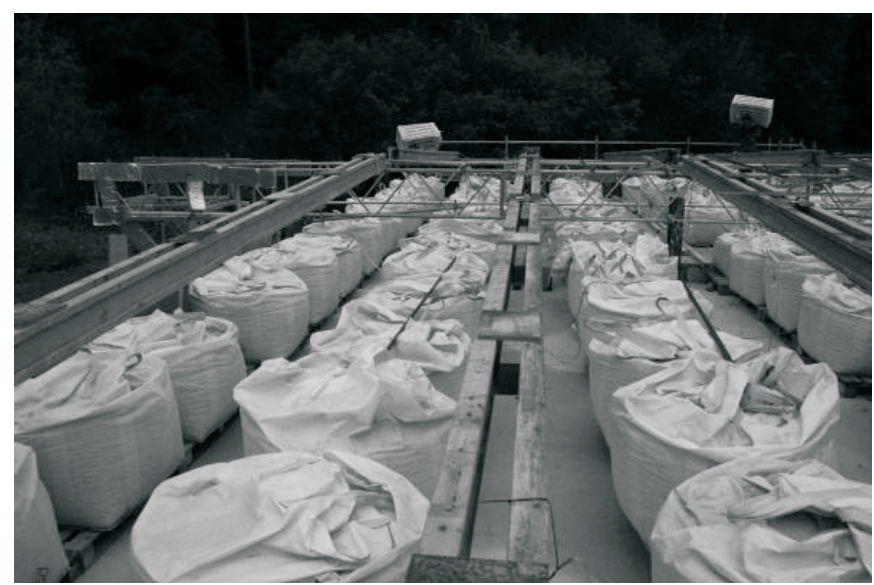

Fig. 3: Position of mechanical load

three/four piles together. The fire test started by reaching a gas temperature of $50{ }^{\circ} \mathrm{C}$. Openings $2.54 \mathrm{~m}$ in height and $8.00 \mathrm{~m}$ in total length with a $1 \mathrm{~m}$ parapet ventilated the compartment. To allow smooth development of the fire, no glazing was installed.

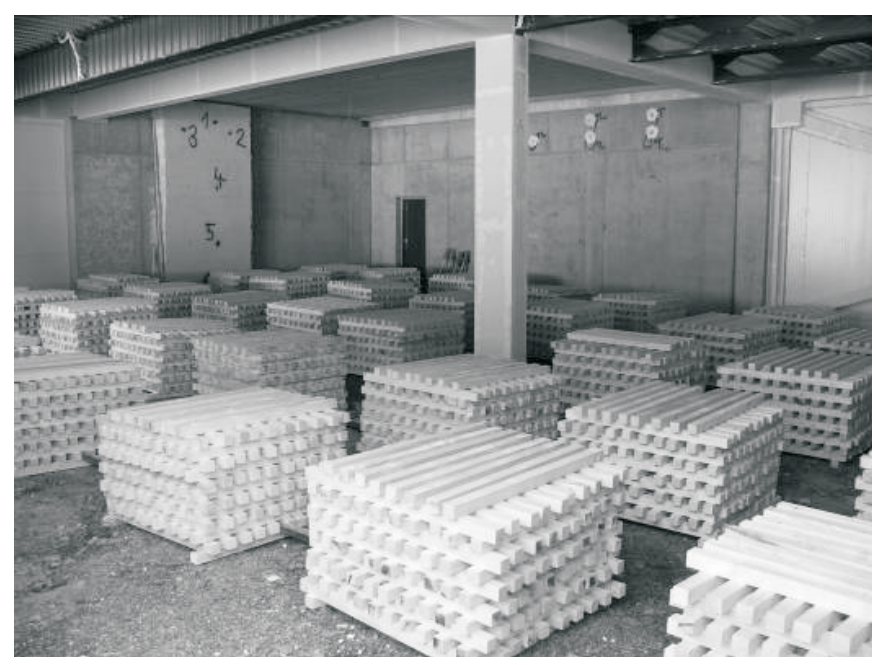

Fig. 4: Distribution of fire load

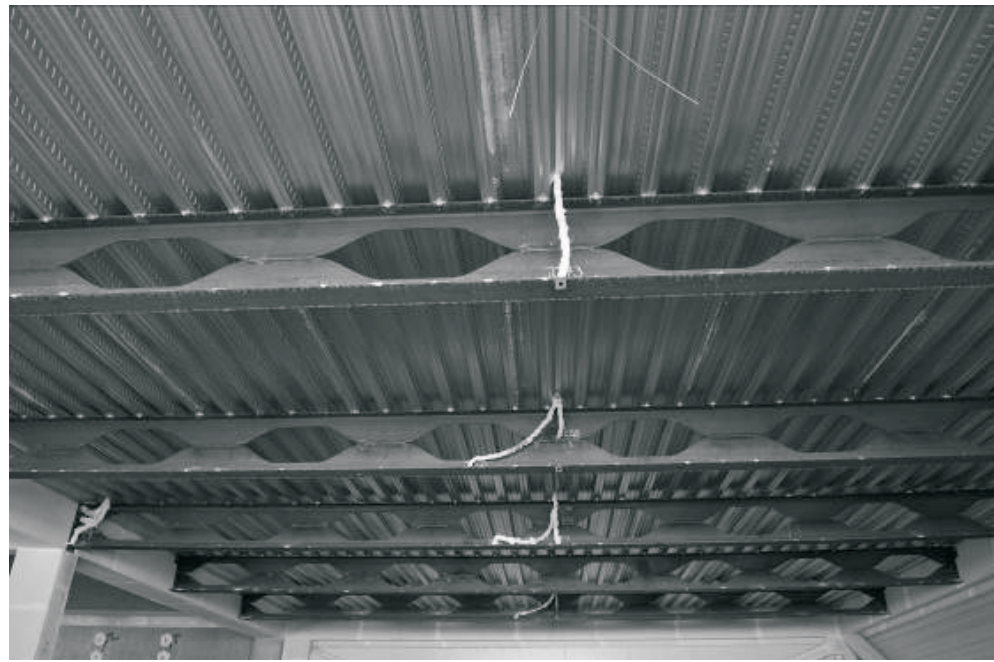

Fig. 5: Thermocouples for gas and steel temperatures 


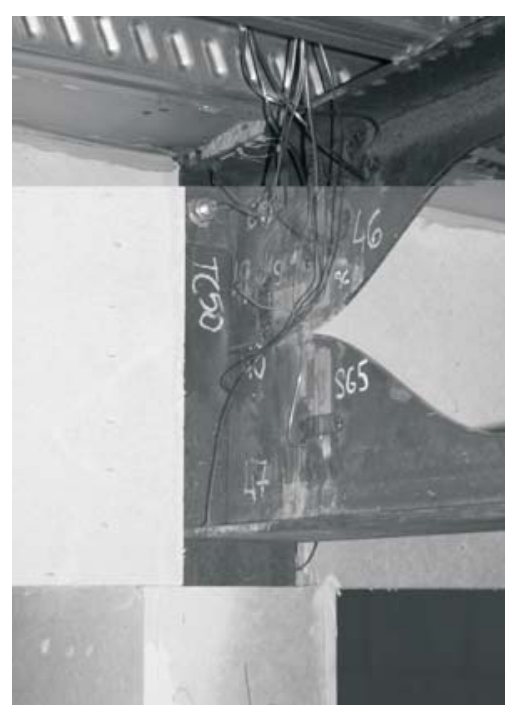

Fig. 6: Thermocouples on beam-to-column connection

\section{Measurements}

The gas temperature in the fire compartment was measured by 14 jacketed $3 \mathrm{~mm}$ thermocouples located $0.5 \mathrm{~m}$ below the ceiling in the level of the lower flanges of the beams, see Fig. 5. Two thermocouples were placed in the openings. The temperature profile along the compartment height was measured between the window and in the back of the fire compartment below the secondary beam. $2 \mathrm{~mm}$ jacketed thermocouples were used for measuring the temperature of the structure. There were 12 thermocouples in the composite slab, on the beams 11, in bolted connections 37, see Fig. 6 , in the hollow core panels 6 , in the concrete wall 16, in the external cladding 24, in the fire pProtected internal column 7, and on the external column 24. On the west linear scaffold a meteorological station was installed to record the external temperature, the wind direction and wind speed. The behaviour was documented by photographs, a video and thermo imaging records.

\subsection{Temperatures}

The prediction of the gas temperatures by the parametric fire curve and by the zone model conservatively expected a temperature of $1057^{\circ} \mathrm{C}$ in $60 \mathrm{~min}$ of fire, see Fig. 7. Under the composite slab with castellated beams, a temperature of $935{ }^{\circ} \mathrm{C}$ was measured in $60 \mathrm{~min}$. At the beginning of the fire, the highest gas temperatures were reached at the front of the fire compartment, and during the fully-developed fire the highest temperatures were at the back of the fire compartment. The east and west part of the compartment showed different temperature developments. In the eastern part of the fire compartment with the concrete wall, a temperature of 810 ${ }^{\circ} \mathrm{C}$ was reached in $21 \mathrm{~min}$, at temperature of $935^{\circ} \mathrm{C}$ in $30 \mathrm{~min}$, and a temperature of $855^{\circ} \mathrm{C}$ in $58 \mathrm{~min}$. In the western part of the fire compartment the developed gas temperature was very similar to the nominal standard fire curve [5]. The temperatures in the two parts of the fire compartment differed due to the different walls, and due to a small change in wind direction during the test.

\subsection{Response of the structure}

The lower flange at the midspan of the unprotected castellated beam AS4 reached $487^{\circ} \mathrm{C}$ in 23 min with deformation $135 \mathrm{~mm}$, see Fig. 8 and 9. In $34 \mathrm{~min}$ of fire, the temperature was $790{ }^{\circ} \mathrm{C}$ and the deflection was $378 \mathrm{~mm}$. The slab failed $62 \mathrm{~min}$ into the test, in the cooling phase of the fire, with a measured temperature of $895{ }^{\circ} \mathrm{C}$ in the lower flange of the beam, at the mid span. The damage to the ceiling started in the southeast corner. The slab lost its resistance in compression $62 \mathrm{~min}$ into the experiment. The edge beam buckled on its developed free length. Due to spalling of the top of the concrete column, the anchors lost their tensile resistance. The bolted connection of the primary box girder was exposed to torsion, which led to loss of its bolt shear resistance.

\subsection{Connection temperatures}

One of the goals of this experiment was to examine connections with higher fire resistance. This was done by encasing them in the concrete slab. The maximum temperature of
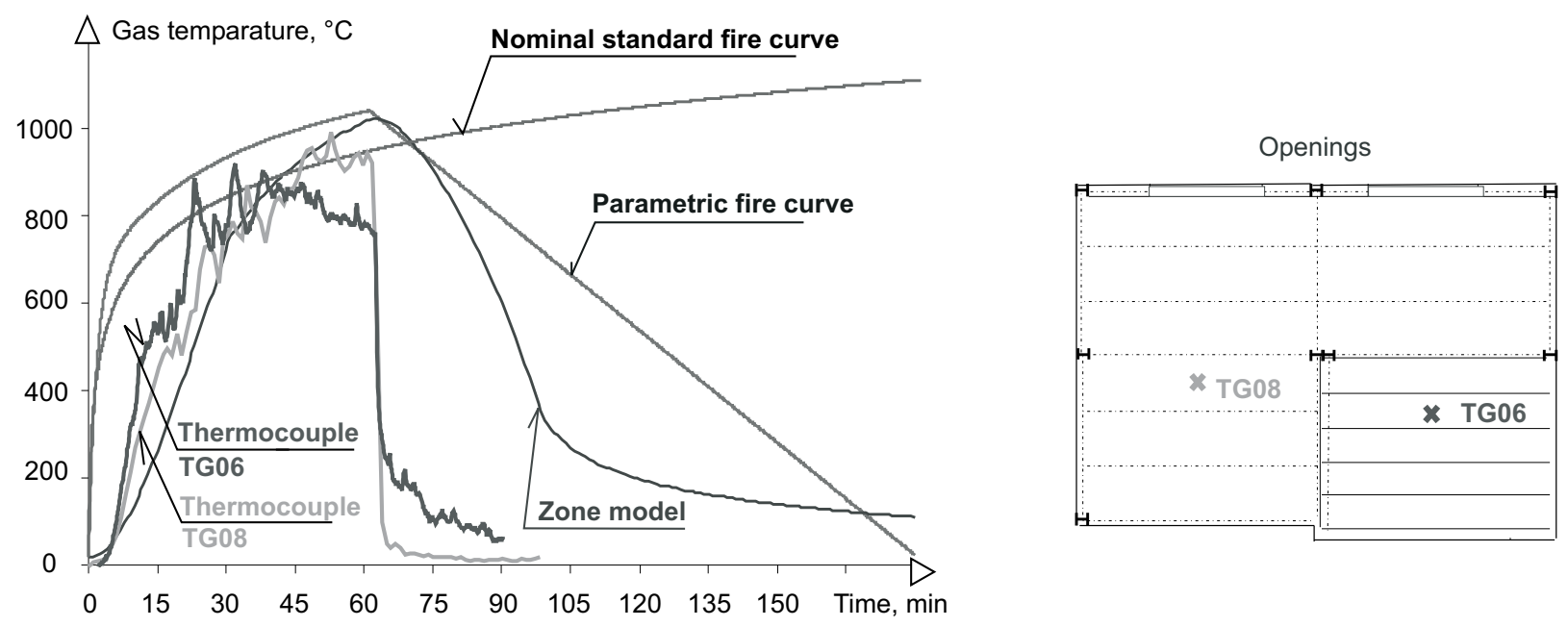

Fig. 7: Comparison of predicted and measured gas temperatures 


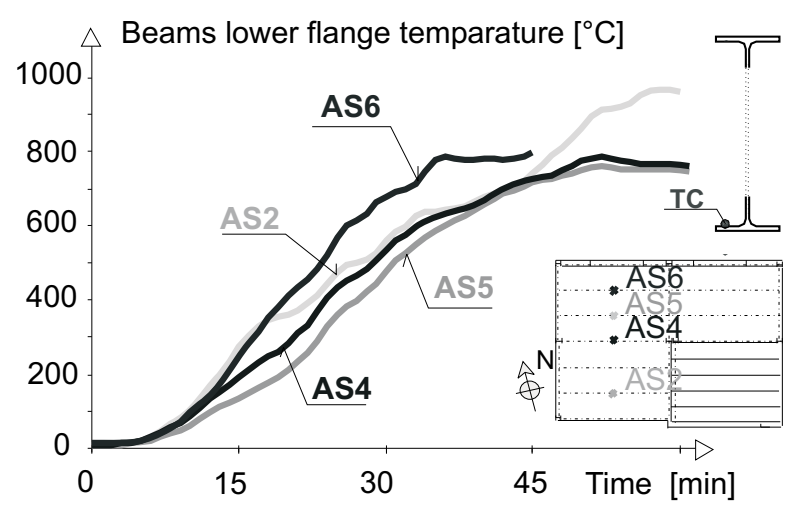

Fig. 8: Temperatures of the lower flanges of the cellular beams

the lower part of the beam-to-column joint was $520^{\circ} \mathrm{C}$, whereas the upper encased part reached a temperature of $157^{\circ} \mathrm{C}$. The highest temperature of the lower flange of the beam in the midspan was $932^{\circ} \mathrm{C}$. In the case of beam-to-beam connections, the temperature differences were similar; the lower part

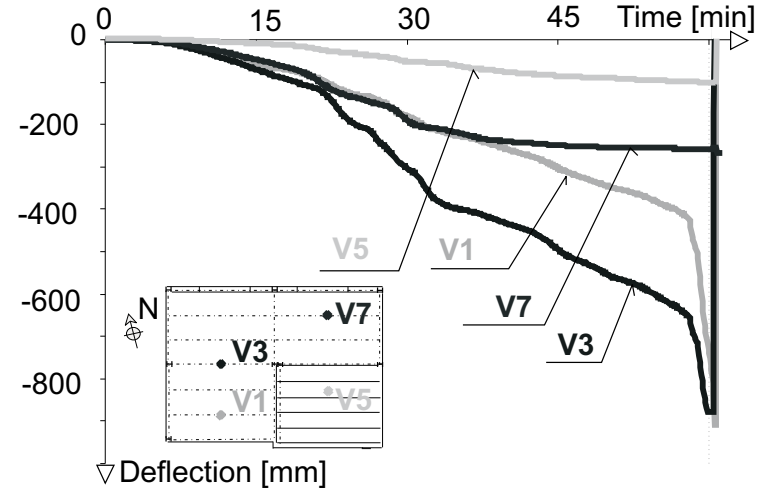

Fig. 9: Deflection of the ceiling

of the joint reached a maximum temperature of $410{ }^{\circ} \mathrm{C}$, and the upper encased part reached $198^{\circ} \mathrm{C}$, while the lower flange at the midspan of the beam reached a temperature of $881^{\circ} \mathrm{C}$. The end plate of the connections deformed plastically before the collapse of the slab, see Fig. 10. Fig. 11 presents the tem-

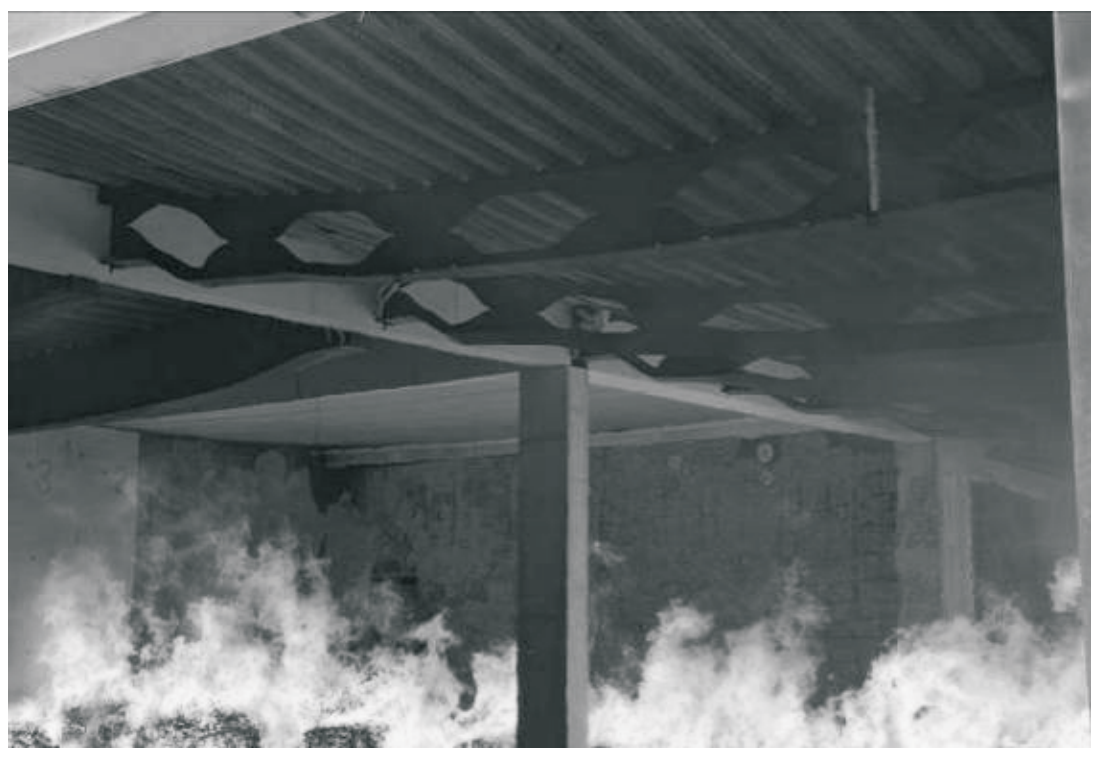

a)

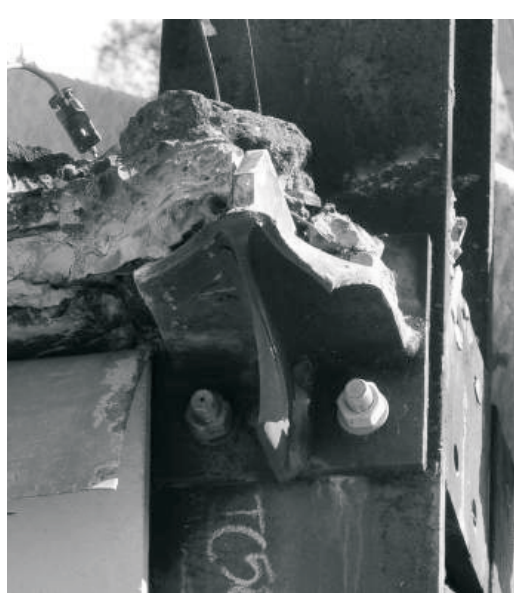

b)

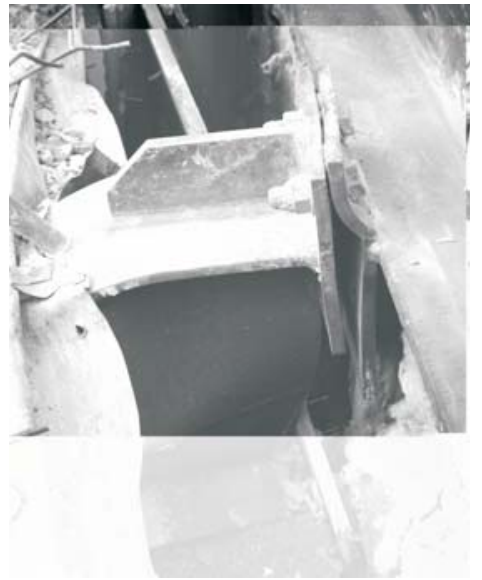

c)

Fig. 10: a) Deflections of the structure in $58 \mathrm{~min}$, b) the beam-to-column connection after the test, c) deformation of the end plate of the beam-to-beam connection 

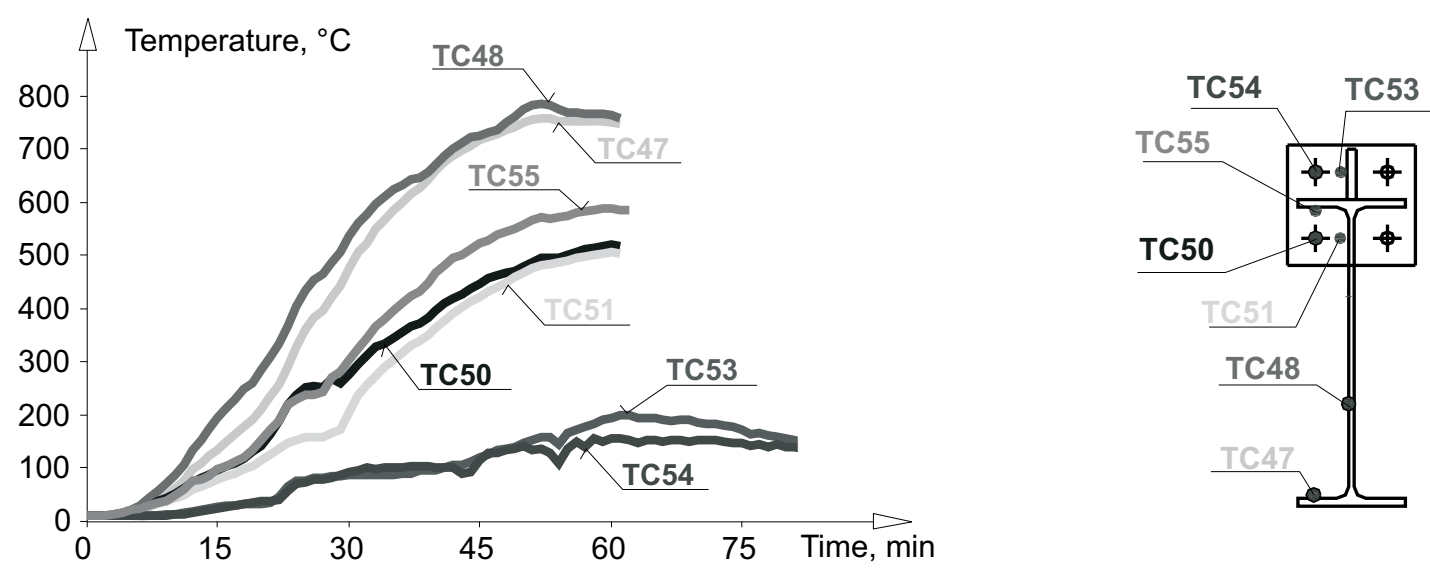

Fig. 11: Temperatures in the beam-to-column connection of the castellated beam AS4
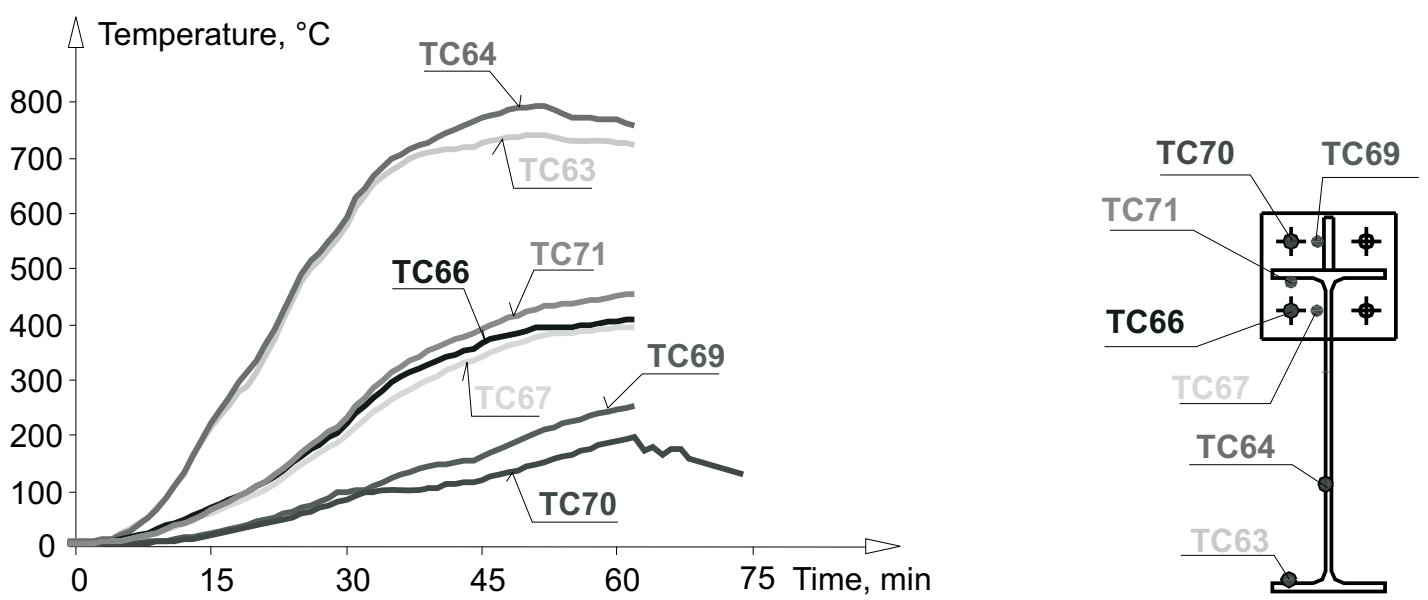

Fig. 12: Temperatures in the beam-to-beam connection of the castellated primary beam AS5

perature in the connection of castellated beam AS4 to the column, and Fig. 12 shows the temperatures of the connection of castellated beam AS5 to the primary beam.
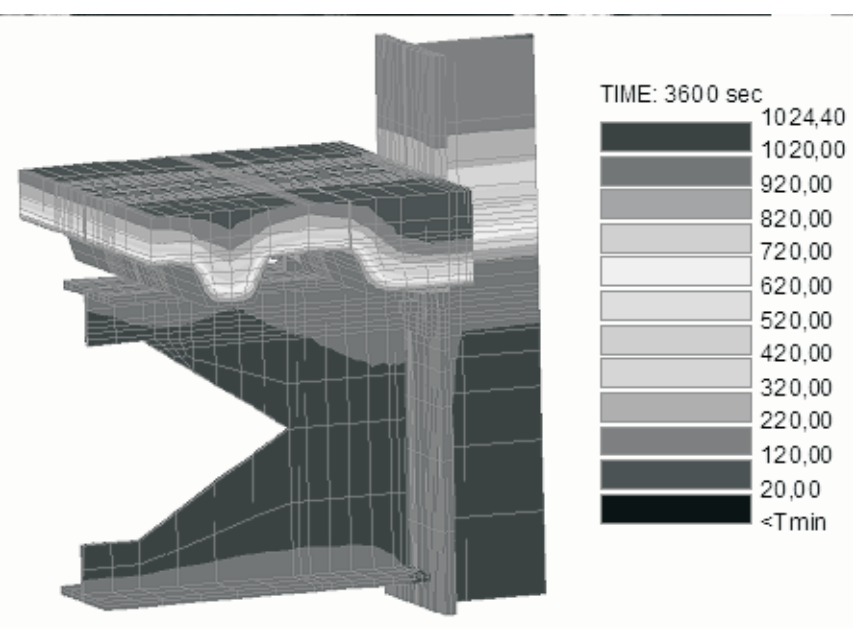

Fig. 13: Simulation of temperatures of the beam-to-column connection in $60 \mathrm{~min}$

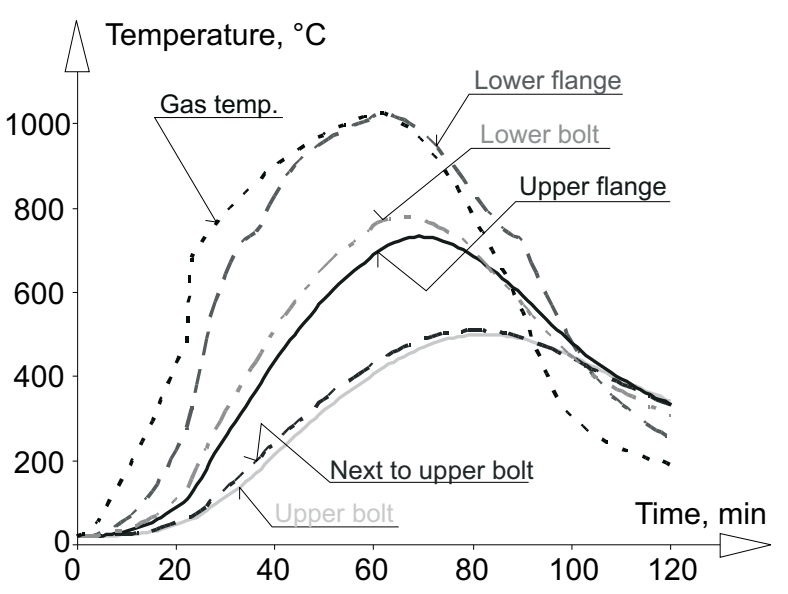

Fig. 14: Predicted temperatures in the connection

The SAFIR program, see [6], was selected to predict the temperature in the connection, which was partially encased in the concrete slab. A 3D model of the joint is shown in Fig. 13. The fire was modelled using the Ozone 2.2 program, see [7]. The predicted temperatures in the connection are shown in Fig. 14. 


\section{Summary}

The fire test shows the differences between the behaviour of the element and of the structure exposed to high temperatures during a fire test. The collapse of the composite slab was reached.

The maximum temperature of the lower bolt in the beam-to-column connection reached $56 \%$ of the temperature in the lower flange in the beam midspan, and the upper encased bolt reached $17 \%$ of the midspan maximum in the flange. In the case of a beam-to-beam connection, the temperature in the lower unprotected bolt was $46 \%$ of the maximum temperature in the flange of the beam in the midspan, while the upper protected bolt reached $22 \%$ of the same maximum temperature.

\section{Aknowledgment}

This work was supported by project No. OC 190 Fire Improved Joints, and by project No. 1M0579 of the CIDEAS Research Centre of the Ministry of Education, Youth and Sports.

\section{References}

[1] Kallerová, P., Wald F.: Požárni zkouška na experimentálním objektu v Mokrsku. Praha: Česká technika -nakladatelství ČVUT v Praze, srpen 2008, ISBN 978-80-01-04146-8.

[2] Wald, F., Simões da Silva, L., Moore, D. B., Lennon, T., Chladna, M., Santiago, A., Beneš, M., Borges, L.: Ex- perimental Behaviour of a Steel Structure under Natural Fire, Fire Safety Journal, Vol. 41 (2006), Issue 7, p. 509-522.

[3] Kallerová, P., Wald, F.: Ostrava fire test, Czech Technical University in Prague, CIDEAS report No. 3-2-2-4/2, p. 18, www.cideas.cz.

[4] Chlouba, J., Wald, F., Sokol, Z.: Temperature of Connections during Fire on Steel Framed Building. International Journal of Steel Structures, accepted for printing.

[5] EN 1991-1-2: 2002. Eurocode 1: Basis of Design and Actions on Structures - Part 2-2: Actions on Structures - Actions on Structures Exposed to Fire, CEN, Brussels.

[6] Franssen, J. M., Kodur, V. K. R., Mason, J.: User's Manual for SAFIR 2004: A Computer Program for Analysis of Structures Subjected to Fire. University of Liège, 2005.

[7] Ozone V2, University of Liège, URL: http://www.argenco.ulg.ac.be/logiciel.php.

Jiří Chlouba

e-mail: jiri.chlouba@fsv.cvut.cz

František Wald

Department of Steel and Timber Structures

Czech Technical University in Prague

Faculty of Civil Engineering

Thákurova 7

16629 Prague 6, Czech Republic 